\title{
Impact of Entrepreneurial Orientation on Bank Performance in Pakistan
}

\begin{abstract}
Nida Nazar
Post Graduate Centre-PGC, Limkokwing University of Creative Technology Cyberjaya, Selangor, Malaysia
\end{abstract}

Dr. Sara Ravan Ramzai

Post Graduate Centre-PGC, Limkokwing University of Creative Technology Cyberjaya, Selangor, Malaysia

Temoor Anjum

Post Graduate Centre-PGC, Limkokwing University of Creative Technology Cyberjaya, Selangor, Malaysia

Imran Ahmed Shahzad (Corresponding author)

Post Graduate Centre-PGC, Limkokwing University of Creative Technology Cyberjaya, Selangor, Malaysia.

Tel: 60-112-602-7044Ｅ-mail: Imran_rana77@hotmail.com

Received: May 8, 2018 Accepted: June 5, 2018 Published: June 30, 2018

doi:10.5296/bms.v9i1.13212ＵRL: https://doi.org/10.5296/bms.v9i1.13212

\begin{abstract}
The purpose of this study is to empirically test the relationship between entrepreneurial orientation dimensions and organizational performance in banking sector of Pakistan. A deductive approach of logic was adopted to formulate the hypotheses. A structured questionnaire was administered to the banking staff to elicit responses regarding the study variables. In order to test the hypothesized relationship, Partial Least Square Structural




\section{Macrothink}

Business Management and Strategy ISSN 2157-6068 2018, Vol. 9, No. 1

equation modelling technique was used. Results of PLS indicated a positive association three dimensions of EO and organizational performance. This study contributes to theory and practice in terms of Pakistani context.

Keywords: Entrepreneurial Orientation, Innovativeness' Risk Taking, Proactiveness, Organizational, Performance, PLS SEM 


\section{Introduction}

Entrepreneurial orientation (EO) is recognized as a crucial success factor for conducting a business, in modern age. On the other hand, deducing new opportunities is mandatory for firms. EO comprises of attributes such as proactivity, innovativeness and risk taking attitude of entrepreneurs (Muenjohn and Armstrong, 2008). The firms are expected to be proactive in comparison to opponents, risk minded and welcoming towards new processes, services and commodities (Hoq and Chauhan, 2011). In the present study, five dimensions of EO enlisted by Lumpkin and Dess (1996), are adopted. Many researchers have explored these dimensions including Lee, Lim and Pathak, (2011), Li, Huang and Tsai, (2009), Hughes and Morgan, (2007), Nonyane-Mathebula, (2010). According to Chen, Du and Chen (2011), EO has enormous contribution towards progress of a company and economy of a country. The success and performance of a company depends entirely on EO as suggested by Mahmood and Hanafi (2013) and Zainol and Ayadurai (2011).EO is important for both the aggressive and delicate surroundings (Walter, Auer and Ritter 2006). Different research works have related EO with the performance of firms (Wang, 2008; Tajeddini, 2010; Hoq and Chauhan, 2011; Schindehutte, Morris and Kocak, 2008; Fauzul, Takenouchi and Yukiko, 2010). The companies and firms having elevated EO, shows better outcomes such as performance in terms of introducing new processes, services and products. Entrepreneurship is compulsory for survival and struggle of firms against their competitors (Teece, 2007). Lindelof \& Lofsten (2006) mentioned that speedy advancement in technology fortifies competition among firms. Resultantly, technological prospects arise leading towards entrepreneurial attitude of companies. The present study will evaluate the association between EO and business performance in the banking segment of Pakistan.

The study starts with introduction to the topic, followed by review of literature. The methodology illustrates procedure followed to perform the study followed by results and discussion section. In this section statistical analysis of the collected data is depicted and compared with previous research works. At the end conclusion will be drawn on the basis of results.

\subsection{Entrepreneurial Orientation (EO)}

The literature has quite an enormous amount of work on EO. Although all the researchers affirm with the beneficial effects of EO, the conceptualization put forward for the term varies (Davis, 2007). According to Lumpkin and Dess (1996), EO is a combination of acts practiced by organizations, which depicts their approach on the basis of criterion implemented in decision making. Covin et al (2006) elaborates EO as entrepreneurial capabilities of a company. Consequently, many research works have explored various features of organizations and related them to EO. All these works have contributed towards concept of EO. Some of the characteristics enlisted by Miller and Friesen (1982) include growth rate, organization's competency with its opponents, and information about strategies of an organization (Miller \& Friesen, 1982). EO can be regarded as an orientation of organization towards acceptability of different procedures and decision making attributed of EO. 
There are three of EO including pro-activeness, autonomy, innovativeness, risk and taking. All these factors may act together or on individual basis to govern EO. However, a good combination of these dimensions can result into progress of a company (Morris \& Sexton, 1996). By reviewing the literature on EO, three research streams can be identified. In first stream, research works have explored the elevated level of EO in the organization (Zahra, 1991). The second stream investigates the relation between EO and organizational performance (Garvis, 2000). The other eminent research stream is based on the features relating EO with performance of organization. Many researchers have been contributed to assess moderating value of different organizational and environmental variables including organizational culture (OC) (Covin, Green, \& Slevin, 2006).

Davis (2007) performed a seminal research with focus on entrepreneurship, in which its dimensions were highlighted. Some research works have pointed as autonomy and competitive aggressiveness as extremely important dimensions of EO. Competitive aggressiveness can be defined as reaction of a company towards varying tendencies of the market (Lumpkin \& Dess, 2001). Autonomy can be defined as liberty of organizations and its members in the course of altering ideas into action (Lumpkin \& Dess, 1996). Despite the fact that many research works have emphasized on considering competitive aggressiveness and autonomy in the EO construct, only limited number of studies have recognized them (Davis, 2007). Consequently, this study has also not considered both of these dimensions. The following sections will elaborate dimensions of pro-activeness, innovativeness and risk taking as a part of EO.

\subsection{Innovativeness}

Innovativeness reflects a company's tendency to get involved in creative processes and develop new ideas resulting in introduction of new services, processes and development of technology (Lumpkin \& Dess, 1996). The previous research of Kimberly (1981) was focused on innovativeness as an organization's capability to introduce new services and products. Later on, Knight (1997) elaborated the concept of innovation as the set of steps taken by an organization towards challenges in constructing and introducing new services and products. Innovativeness also includes all activities and processes of a company whether managerial, technological or administrative in nature. According to Cero et al., (2009), innovation can be whether rational or incremental. To improve previous products, introduce new features to them or to initiate new products in order to meet ever changing demands of customers.

Innovativeness and inventiveness are regarded as two different entities by Hitt, Hoskisson and Nixon (1993). Inventiveness is recognized as initial step of innovativeness. It can be defined as a company's leniency towards introduction of new products, ideas and services by creativity and trials. Inventiveness is important as it is the initiator of new opportunities for a company. Thus, the companies' needs to promote inventiveness as it may result in introduction of new criteria for values and strategic position for company in the market (Sharma \& Dave, 2011). Bruder \& Preisendorfer, (2000) defined innovativeness as the basis of success of entrepreneurial organization (Drucker, 1985). Miller and Friesen (1982) 
proposed two innovation models including entrepreneurial model and conservative model. The adoption of these models by companies depends on their types. An organization may adopt conservative model to uphold its place in dynamic market. On the other hand, entrepreneurial model is adopted by an organization to compete with opponents, without any consideration of market dynamics (Sharma \& Dave, 2011).

Many research works have differentiated innovation types on the basis of innovation actions including marketing activities, product designing and technical innovation. Due to close interrelation of innovation types, their differentiation is highly difficult (Lumpkin \& Dess, 1996). Innovativeness acts as a determinant of an organization's performance (Brown \& Eisenhardt, 1998) and its tendency to consider the benefits of initiator (Wiklund, 1999). Innovativeness is regarded as most significant basis of illustrating entrepreneurship. Therefore, majority of the researchers has identified innovativeness as the most important feature of entrepreneurship profile. It is considered to add value to the role of entrepreneurs (Sharma \& Dave, 2011). Innovativeness aids in performance and productivity of entrepreneurial organizations (Covin \& Miles, 1999; Covin \& Wales, 2010). Moreover, innovativeness is detrimental of cultural advanciness of an organization with realization of innovation need (Hurley, Hult, \& Knight, 2005).

\subsection{Proactiveness}

Proactiveness can be defined as an organization's will to cope up with the changing needs of market and seek for various opportunities that are either or not in accordance with its goals. This may lead towards introduction of new products of services in order to achieve customer satisfaction and dynamic requirements of market (Venkataraman, 1989). According to Frank, Kessler and Fink (2010), Proactiveness involves an organization's enthusiasm and capability to predict changes and become primary initiators among competitors, instead of waiting and then reacting slowly to the new development. Thus, a proactive organization is always initiators and risk takers towards dynamic trends of market. They are always ready for developing new products and services; thus, take an edge over the opponents (Davis, 2007).

The literature emphasizes on significance of a firm's speedy reaction towards availing of various opportunities and an organization's capability to avail opportunities of introducing new services and products (Miller \& Friesen, 1982). The most important element of proactiveness has been regarded as firm movement (Davis, 2007; Miller, 1983). The initial definitions set forward for proactiveness were subjected to differentiate competitive aggressiveness from proactiveness. Competitive aggressiveness refers to a company's reaction towards market demands and varying customer needs (Lumpkin \& Dess, 1996). On the other hand, proactiveness reflects a company's willingness towards getting involved in new business prospects. Previous researches have referred to proactiveness as a deed of organizations to be initiators of developing and advertising new products and services (Kraus \& Kauranen, 2009). Thus, proactive organizations act as leaders for all the other companies (Sharma \& Dave, 2011). They have superior levels of imagination, performance and commitment (Caruana et al., 2002). 


\subsection{Risk-Taking}

The leniency of an entrepreneur towards acceptance of risk taking behaviour is considered as a critical factor for EO profile (Davis, 2007). The inclination towards risk taking differentiates entrepreneur from all the other members of an organization. Risk taking reflects the attitude of an individual towards resource commitments (Miller \& Friesen, 1978). Risk taking relates to entrepreneur behaviour through the fact of uncertainty (Kraus et al., 2012).

There are three types of risks according to Baird and Thomas (1985). The risk debt used to initiate a business, investment of resources in a new business and unveiling new fields of business. Risk taking is a significant feature of EO that depicts entrepreneurship (Osman, Rashid, Ahmed, \& Hussain, 2011).

\subsection{Organizational Performance}

Plenty of research works have explored aspect of organizational performance under organizational studies (Simpson, Padmore, \& Newman, 2012). Its significance lies in the impact on organizational development, competitiveness and effectiveness (Sulaiman, Yusoff, \& Chelliah, 2010). The competition in quality and quantity has tremendously been enhancing in the global market. Anyhow, the clients have specificities regarding quality of services or products they buy. Thus, an environment has built up with great emphasis on changing demands and needs of customers. This has compelled the companies to implement various strategies that may help in upholding high quality standards to maintain their position in the world market. The implementation of TQM practices and entrepreneurship among organizations has been explored by many researchers in organizational studies.

The literature on management manifests that organizational performance is the most important aspect in strategic management area (Combs, Crook \& Shook, 2005). From the previous many years, research has been carried out on organizational performance in order to identify ancestors, methods and features that can help in improving organizational outcomes (Jing \& Avery, 2011). Major part of this research was motivated by practical implication of organizational performance which originates from high management level, which is focused on competition and success of an organization (Finkelstein \& Hambrick, 1996). The service providing organizations mainly aspire to render products and services to customers in accordance with their demands and requirements (Al-Marri, et al., 2007). Therefore, many research works have been dedicated to explore effectiveness of service sector.

\subsection{The Performance Measurement in the Present Study}

The financial performance is essential in evaluating accomplishment of profit based organizations, whereas, the non financial performance is significant in assessing success for service and profit organizations (Kaplan \& Norton, 2000). Anyhow, research works relevant to performance measurements depict that financial measurement system has been criticized for disregarding many prospects of organizational performance (Arnand, 2003). However, non-financial perspectives have always been acknowledged as they are focused on 
determining causes (Arnand, 2003). Moreover, they depict present scenario of management (Banker, Potter \& Srinivasan, 2000) and are subjected towards service quality and customers requirements (Banker et al., 2000).

The association of non financial and financial performance has been studied by many scholars including York and Miree (2004) and Rust, Zahorik and Keiningham (1995). The aspects of non financial performance such as quality, client satisfaction and innovativeness results in increase of market share and customer devotion. Both these factors lead towards enhanced financial performance. Both objective and subjective measures can be utilized to evaluate non financial and financial performance. The subjective measure utilizes self reported responses from organization's members, whereas, objective measures consider figurative aspects of organization to evaluate organizational performance (Johannessen et al., 1999).

The present study affirms to evaluate non financial performance through perceptual measures on the basis of following assumptions. The perceptual measures have high reliability and equivalent to subjective measures. Thus, both measures equal level of performance (Ackelsberg \& Arlow, 1985). The participants may get suspicious about privacy of financial data. This is highly true for a business environment of Pakistan. The subjective assessment assists for forecasting opportunities for organizational performance (Pizam \& Ellis, 1999). Thus, the present study would utilize perceptual measure to assess organizational performance of Pakistani banks.

\section{Hypothesis Development}

\subsection{Entrepreneurial orientation (EO) and Organizational Performance}

Many research works have been attributed to conceptualize EO. Some studies have assessed EO, whereas, others have evaluated its association with performance. On the other hand, several studies have analyzed influential relation of EO dimensions with organizational performance (Davis, 2007). In the present study, hypothesis has been constructed by relating EO dimensions with organizational performance.Many researchers have evaluated association between EO and performance of organization in term of entrepreneurship (Davis, 2007). All these researches have shown positive association of EO with organizational performance (Covin \& Slevin, 1986; Drucker, 1985). Covin and Slevin (1991) and Zahra and Dess (2001) claimed that although many research works promote association of EO with organizational performance, strong empirical basis are required to justify it.

Some research works have deduced influence of EO on organizational performance, whereas, others have affirmed the relation to exist in opposite direction ( $\mathrm{Li}$ et al., 2009; Wiklund \& Shepherd, 2005). Keh et al (2007) explained that companies with higher entrepreneurship abilities tend to avail business opportunities and scores competitive edge over opponents.The research works related to entrepreneurship have depicted affirmative association between EO and performance. On the other hand, some studies have indicated insignificance of association between performance and EO (Brown, Davdisson \& Wiklund, 2001; Kaya \& 


\section{Mll Macrothink}

Syrek, 2005). Ramachandran (2003) explained that EO can add in the company's value by recognizing reasons of customer dissatisfaction to find their possible solutions. According to him, implementation of EO is still in initial stages for developing countries. Dwairi (2007) studied banks of Jordan on the basis of their performance and claimed that difference between them is due to tendency towards EO implementation. The Pakistani banks have different levels of performance; thus, it can be deduced that EO has varying influence on performance of Pakistani banks. Varying results have been reported regarding relation of EO with organizational performance. A considerable number of works have indicated that higher EO results in higher level of competitiveness, productivity and performance (Covin \& Slevin, 1991; Wiklund, 1999 Zahra \& Covin, 1995). On the other hand, some research works have notified that there is a lack of literature on entrepreneurship in developing countries (Lazer \& Hardin, 1994). Thus,

Hypothesis 1: A significant relation exists between entrepreneurial orientation and organizational performance.

\subsection{Innovativeness and Organizational Performance}

According to multidimensional approach towards EO, it is crucial to evaluate relationship of each aspect with organizational performance. Thus, it is important to study relationship of proactiveness, innovativeness and risk taking with organization performance on individual basis (Davis, 2007). According to Shane and Ventakaraman (2000), innovativeness forms the core of entrepreneurship and counteracts with the entrepreneurship concerns. With increasing uncertainty in organizational environment, innovativeness demand increases (Kropp et al 2006). Through innovativeness and creativity, organizations get an advantage over competitors. Thus, innovativeness is a crucial performance determinant (Miller, 1983). Thus, it is hypothesized that

Hypothesis 2: A significant relation exists between innovativeness and organizational performance.

\subsection{Proactiveness and Organizational Performance}

Previous research works emphasized that proactiveness forms an important factor for entrepreneurship (Miller, 1983). Innovativeness reflects capability of an organization to develop and introduce new services and products to meet the demands of clients and market. Proactiveness reflects capacity of a firm to forecast future perspective and retort in the form of products and services towards various opportunities. It refers to creative abilities of an organization (Covin \& Miles, 1999). Many research works have indicated the importance of proactiveness for organizations and affirmed the presence of positive relationship between proactiveness and organizational performance (Bhuian, Menguc \& Bell, 2005; Lumpkin \& Dess, 2001). Thus, it is hypothesized that

Hypothesis 3: A significant relation exists between proactiveness and organizational performance. 


\subsection{Risk-taking and Organizational performance}

Risk taking refers to an organization's tendency towards risky resources of business activities (Lumpkin \& Dess, 1996). By taking risk, an organization has two possibilities, either to fail or to miss the opportunity (Dickson \& Giglierno, 1986). Thus, risk taking is an important factor for success of an organization. The absence of risk taking hinders the organization from achieving market opportunities (Hughes \& Morgan, 2007). The factors of risk taking and opportunity seeking help organizations to achieve perspective of opportunity exploitation (Lumpkin \& Dess, 1996). If the risks are avoided by organizations, efficient strategies for product development cannot be achieved. The organizations would not be able to perform competitively in the dynamic market (Miller and Friesen 1982). Thus, in order to maintain competitiveness, organizations have high tendency towards risk taking behaviour (Hughes \& Morgan, 2007). Thus, it is hypothesized that

Hypothesis 4: A significant relation exists between risk-taking and organizational performance.

\section{Methodology (Measures of the study)}

\subsection{Organizational Performance Scales}

Organizational performance measurement was obtained from studies in literature dedicated to management. Specifically, Narver and Slater's (1994) and Jaworksi and Kohli‘s (1993) measures were adopted to measure performance. Chapter three provided that the measure for this construct comprised of items confined to non- financial performance. As such, some items were adopted from Chan (2004), Fuentes-Fuentes (2004), and Kaplan and Norton (1992). The items employed to measure organizational performance construct of bank branches along with their sources are exhibited in appendix

\subsection{Entrepreneurial Orientation (EO) Measure}

The pioneering developed measure for EO was proposed by Khandwalla (1977) and was later followed by Miller and Friesen's (1983) five-item scale. Several researchers conducted extensive examination to create later measures including those proposed by Covin and Slevin (1986, 1989) and Smart and Conant (2011). Much later, a major portion of literature dedicated to EO focused on three dimensions namely innovativeness, proactiveness and risk-taking. The present study adopted Covin and Slevin's (1989) items to measure EO as listed in appendix.

\subsection{Data Collection}

The appropriate survey administration considerably impacts the satisfactory responses of the data gathered. Hence, the present study made use of self- administered questionnaire as the primary tool for data collection. In this regard, the quantitative method of study is invaluable in transformation information using the questionnaire into significant outcomes that contributes to research development (Cooper \& Schindler, 2006). As mentioned, the 
questionnaire comprised 80 items measured with the help of a 5 point Likert scale, and the researcher specifically followed the self-administration approach in the cities where the bank branches were situated to guarantee significant rate of response. Such a method allowed the respondents to clarify ambiguities and the data collectors to confirm missing data from the respondents. Some bank branches were assisted by their headquarters in providing the much needed data. Data were collected from 200 Pakistani banks.

\section{Data Analysis}

After data collection procedure, descriptive and inferential statistics were used for data analysis. In particular, the PLS-SEM method was employed to analyze the collected data. The Partial Least Squares technique is a powerful component-based method widely used in prior studies (Farrukh, Khan, et al., 2017; Farrukh, Chong, Mansori, \& Ravan Ramzani, 2017; Farrukh, Wei Ying, \& Abdallah Ahmed, 2016; Farrukh, Ying, \& Mansori, 2016, 2017; Riaz, Farrukh, Rehman, \& Ishaque, 2016; Shahzad, Farrukh, Kanwal, \& Sakib, 2018).PLS SEM is a two-step process in the first step measurement/ outer model is evaluated for validity and reliability while in the second step path coefficients are tested for significance.

\subsection{Measurement Model}

Prior to hypotheses testing, the Partial Least Squares Structural Equation Modeling (PLS-SEM) was employed to assess the measurement model's outer model. The following phases, suggested by James C Anderson and Gerbing (1988) were followed. This process confirms construct validity. Construct validity can be accessed through the construct's content validity, convergent validity and Discriminant validity. Table 1 shows the results of measurement model evaluation.

Table 1. Measurement Model evaluation

\begin{tabular}{|c|c|c|c|c|c|}
\hline Construct & Items & Loading & Cronbach's Alpha & $\mathbf{C R}$ & AVE \\
\hline \multirow[t]{3}{*}{ Innovativeness } & I1 & 0.838 & 0.871 & 0.921 & 0.795 \\
\hline & $\mathrm{I} 2$ & 0.92 & & & \\
\hline & I3 & 0.915 & & & \\
\hline \multirow[t]{6}{*}{ Organizational Performance } & OP1 & 0.907 & 0.894 & 0.921 & 0.664 \\
\hline & OP2 & 0.891 & & & \\
\hline & OP3 & 0.813 & & & \\
\hline & OP4 & 0.73 & & & \\
\hline & OP5 & 0.888 & & & \\
\hline & OP6 & 0.621 & & & \\
\hline \multirow[t]{3}{*}{ Proactiveness } & $\mathrm{P} 1$ & 0.859 & 0.88 & 0.926 & 0.807 \\
\hline & $\mathrm{P} 2$ & 0.901 & & & \\
\hline & P3 & 0.934 & & & \\
\hline \multirow[t]{3}{*}{ Risk- Taking } & R1 & 0.889 & 0.799 & 0.882 & 0.713 \\
\hline & $\mathrm{R} 2$ & 0.795 & & & \\
\hline & R3 & 0.848 & & & \\
\hline
\end{tabular}




\subsection{Discriminant Validity Analysis}

In order to ensure further construct validity of the outer model, the discriminant validity is important to be established. Hence, prior to hypotheses testing, discriminant validity was ensured. Discriminant validity refers to the level to which items can differentiate among different constructs in that it shows that the items of different constructs are not overlapping. Additionally, Discriminant validity of measures share variance between each individual construct and hence it should be higher than the variance shared among specific constructs (Compeau, Higgins \& Huff, 1999). In this study, the Discriminant validity of measures was established through Fornell and Larcker's (1981) method, where the square root of AVE for the entire constructs was replaced at the diagonal elements of the correlation matrix as demonstrated in Table 2.

Table 2. The Discriminant Validity Matrix

\begin{tabular}{llllll}
\hline & & I & OP & P & R \\
\hline $\mathrm{I}$ & & $\mathbf{0 . 8 9 2}$ & & & \\
& OP & 0.667 & $\mathbf{0 . 8 1 5}$ & & \\
$\mathrm{P}$ & 0.848 & 0.683 & $\mathbf{0 . 8 9 8}$ & \\
$\mathrm{R}$ & 0.684 & 0.611 & 0.729 & $\mathbf{0 . 8 4 5}$ \\
\hline
\end{tabular}

\subsection{Structural Model Evaluation}

After the confirmation of the goodness of the outer model, the next phase involves the testing of hypotheses relationships among the variables with the help of PLS Algorithm, Smart PLS. The path coefficients were produced and presented table 4 .

The Results of the Inner Structural Model

\begin{tabular}{|l|c|c|c|l|l|l|}
\hline Hyp.No & Hypothesis & $\begin{array}{c}\text { Path } \\
\text { Coefficient }\end{array}$ & $\begin{array}{c}\text { Standard } \\
\text { Error }\end{array}$ & T-Value & P-Value & Decision \\
\hline H2 & EO -> OP & $0.570^{* * *}$ & 0.0872 & 6.539 & 0.000 & Supported \\
\hline H2a & I -> OP & $0.198^{*}$ & 0.142 & 1.398 & 0.081 & Supported \\
\hline H2b & P -> OP & $0.234^{* *}$ & 0.114 & 2.058 & 0.020 & Supported \\
\hline H2c & R -> OP & $0.137^{* *}$ & 0.079 & 1.734 & 0.042 & Supported \\
\hline
\end{tabular}

$*: \mathrm{p}>0.10 ; * *: \mathrm{p}>0.05 ; * * *: \mathrm{p}>0.01$

\section{Discussion}

\subsection{Entrepreneurial Orientation (EO) and Organizational Performance}

In the present study, it was found that EO has positive and significant influence on organizational performance with $\beta=0.570, t=6.539(p<0.05)$. This approves hypothesis 2 under justification from previous works of Mahmood \& Hanafi, (2013), Dada \& Watson, (2013), Tang \& Tang, (2012), Al-Swidi \& Al-Hosam, (2012), Campos \& Valenzuela, (2013), 
Saeed et al., (2014), Wang \& Yen, (2012), Li et al., (2009), Arief et al., (2013), Zhang \& Zhang, (2012), Abebe, (2014), Miller, (1983), Sciascia et al., (2014), Liu \& Liu, (2011) and Keh et al., (2007). The EO strategy helps organizational leaders to boost up organizational perspectives for better growth and survival of the firm against the competitors. Thus, EO is important for Pakistani banks in order to gain organizational performance. Entrepreneurship is mandatory for an organization to survive and progress (Wiklund and Shepherd, 2003). However, the research works of Slater and Narver (2000), George, Wood and Khan (2001), Dimitratos, Lioukas and Carter (2004), and Walter, Auer and Ritter (2006) have not supported the affirmative influence of EO. On the other hand, the studies with positive interpretation have shown direct link of entrepreneurship with organizational performance. Moreover, the bank leaders require tendency towards availing of opportunities along with entrepreneurship in order to avail competitive edge over opponents.

\subsection{EO-Innovativeness and Organizational Performance}

The present study has indicated positive relationship between innovativeness and organizational performance $\beta=0.198, \mathrm{t}=1.398(\mathrm{p}<0.10)$. Thus, the hypothesis $\mathrm{H} 2 \mathrm{a}$ is justified. Previous studies have also shown that innovativeness results in enhanced productivity, profit and organizational progress (Brown \& Eisenhardt, 1998; Covin \& Miles, 1999; Covin \& Wales, 2010; Jalali, 2012; Wang \& Yen, 2012; Wiklund, 1999).

\subsection{EO-Proactiveness and Organizational Performance}

The present study has shown that proactiveness has positive influence on organizational performance $\beta=0.234, t=2.058,(p<0.05)$. Thus, the hypothesis $\mathrm{H} 3 \mathrm{~b}$ is justified and indicates that proactiveness is associated with organizational performance. The same has been supported by research works of Wang and Yen (2012), Caruana et al. (2002), Lumpkin and Dess (2001), Kraus et al. (2012), and Bhuian et al., (2005). The significance of proactiveness in Pakistani banks can be grasped through these results.

\subsection{EO-Risk Taking and Organizational Performance}

The present study found that risk taking has positive influence on organizational performance $\beta=0.137, \mathrm{t}=1.734,(\mathrm{p}<0.05)$. This justifies hypothesis $\mathrm{H} 2 \mathrm{c}$ that there exists a positive and significant relationship between risk taking and organizational performance. These results are supported by the works of Wang and Yen (2012), Hughes and Morgan (2007), Miller and Friesen (1982) and Kraus et al. (2012).

\subsection{Contributions}

The present study justifies relation of various dimensions with organizational performance of Pakistani banks. It is one of the few studies conducted in South Asia to address effect of EO dimensions on organizational performance. The present study is a contribution towards literature of EO. The present study helps to understand relationship between EO and organizational performance. On the basis of findings postulated by previous research works, the framework of present study was assessed. This study contributes towards 
conceptualization of EO and its importance towards organizational performance. Although previous research works have evaluated this relationship, no consistency has been indicated in their results. This study will help in obtaining consensus about this relationship. Due to inconsistency in the results, many academics and researchers have called for additional research on EO strategy for organizational performance (Wiklund \& Shepherd, 2005). The present research work has confirmed that there exists a positive and significant relationship between EO and organizational performance.

\subsection{Practical Contributions}

The present research work has practical implications for workers in different organizations. The findings of present work are useful in understanding impact of EO on organizational performance and deploying it to attain a positive relationship. Entrepreneurship has primary importance for survival and growth of an organization. Thus, members of management working in Pakistani banks should implement effective planning to enhance entrepreneurship.

\subsection{Limitations of the Study}

Like all other studies, the present research work was confined with some limitations. Cross sectional research design was used to analyze hypothesis of the study. However, psychological perspectives keep changing over time. Thus, longitudinal design can depict better and realistic results.

$\checkmark$ Another limitation is the use of quantitative research method, in which participants indicate their perceptions on questionnaires through Likert scale. The responses of the participants can be influenced by their biased knowledge on the issue (Macinati, 2008). Thus, the future research works should implement mixed research design, which consists of both the qualitative and quantitative research designs.

$\checkmark$ The most important limitation is the meagre amount of previous research works present on the subject in context of Pakistan. Thus, it imparts limitation in comparing with previous research works.

\subsection{Suggestions for Future Research}

$\checkmark$ The present study turns milestones down and paves way for future research dimensions. The data collection was performed through cross sectional method; thus, there is a space for longitudinal approach. This will help in depicting relationship over different time spans and understand development of variables and the changes occurring in them.

$\checkmark$ In order to assess impact of EO on organizational performance, case study should be used. This will help in examining relationships in detail and deduce better information. The present study includes data from Pakistani banks. The future research works can include viewpoints of employees and customers. 


\section{Macrothink}

$\checkmark$ In order to check generalizability of results, the future research works can examine each construct individually. The same model can be used to study various market sectors. By changing regions and countries, better information can be gathered.

\section{Conclusion}

The organizational performance of banking sector is extremely important for economy and progress of a country. In developing countries, there is a high concern about organizational performance of banks. Consequently, EO has been recognized as an important approach in obtaining higher organizational performance and produce innovativeness. Although both the constructs are acknowledged in Pakistan, these strategies are in their primary stages. The present study depicts positive influence of EO on organizational performance. This concept was first put forward in West, but has now been implemented in Pakistani banks and positive results have been obtained so far.

\section{References}

Abebe, M. (2014). Electronic commerce adoption, entrepreneurial orientation and small-and medium-sized enterprise (SME) performance. Journal of Small Business and Enterprise Development, 21(1), 100-116.

Ackelsberg, Robert, \& Arlow, Peter. (1985). Small businesses do plan and it pays off. Long Range Planning, 18(5), 61-67.

Al-Marri, Khalid, Ahmed, Abdel Moneim M Baheeg, \& Zairi, Mohamed. (2007). Excellence in service: an empirical study of the UAE banking sector. International Journal of Quality \& Reliability Management, 24(2), 164-176.

Al-Swidi, Abdullah Kaid, \& Al-Hosam, Asma. (2012). The effect of entrepreneurial orientation on the organizational performance: A study on the Islamic banks in Yemen using the partial least squares approach. Arabian Journal of Business and Management Review (OMAN Chapter), 2(1),73-84.

Anderson, James C, \& Gerbing, David W. (1988). Structural equation modeling in practice: A review and recommended two-step approach. Psychological bulletin, 103(3), 411.

Arief, Mohammad, Thoyib, Armanu, Sudiro, Achmad, \& Rohman, Fatchur. (2013). The effect of entrepreneurial orientation on the firm performance through strategic flexibility: A study on the SMEs cluster in Malang. Journal of Management Research, 5(3), 44-62.

Baird, Inga Skromme, \& Thomas, Howard. (1985). Toward a contingency model of strategic risk taking. Academy of Management Review, 10(2), 230-243

Banker, R.D., Potter, G., \& Srinivasan, D. (2000). An empirical investigation of an incentive plan that includes non-financial performance measures. The Accounting Review, 75(1),65-92.

Bhuian, Shahid N, Menguc, Bulent, \& Bell, Simon J. (2005). Just entrepreneurial enough: the moderating effect of entrepreneurship on the relationship between market orientation and 
performance. Journal of business research, 58(1), 9-17.

Brown, R. (1993), Market Focus, Butterworth-Heinemann, Oxford.

Brown, Roger L. (1997). Assessing specific mediational effects in complex theoretical models. Structural Equation Modeling: A Multidisciplinary Journal, 4(2), 142-156.

Brown, S. L. \& Eisenhardt, K. M. (1998). Competing on the Edge, Boston, MA: Harvard Business School Press.

Brown, Terrence E, Davidsson, Per, \& Wiklund, Johan. (2001). An operationalization of Stevenson's conceptualization of entrepreneurship as opportunity-based firm behavior. Strategic management journal, 22(10), 953- 968.

Campos, Héctor Montiel, \& Valenzuela, Francisco Alfonso Aguilar. (2013). The relationship between entrepreneurial orientation, time orientation and small business performance: an evidence from Mexico. Revista da Micro e Pequena Empresa, 7(1), 48-63.

Caruana, Albert, Ewing, Michael T, \& Ramaseshan. (2002). Effects of some environmental challenges and centralization on the entrepreneurial orientation and performance of public sector entities. Service Industries Journal, 22(2), 43- 58.

Chelliah, S., Sulaiman, M., \& Yusoff, Y. M. (2010). Internationalization and performance: Small and medium enterprises (SMEs) in Malaysia. International Journal of Business and Management, 5(6), 27.

Combs, James G, Crook, T Russell, \& Shook, Christopher L. (2005). The dimensionality of organizational performance and its implications for strategic management research. Research methodology in strategy and management, 2, 259-286.

Compeau, Deborah, Higgins, Christopher A, \& Huff, Sid. (1999). Social cognitive theory and individual reactions to computing technology: A longitudinal study. MIS quarterly, 145-158.

Cooper, D. R., \& Schindler, P. S. (2006). Business Research Methods (9th ed.). New York, NY.: McGraw-Hill

Covin, J. G. \& Wales, W. J. (2010). The Measurement of Entrepreneurial Orientation. Paper presented at the at the Annual Meeting of the Academy of Management (AoM), Montreal, QC.

Covin, J., \& Miles, M. (1999). Corporate entrepreneurship and the pursuit of competitive advantage. Entrepreneurship: Theory \& Practice, 23(3), 47-63.

Covin, Jeffrey G, \& Slevin, Dennis P. (1986). The development and testing of an organizational-level entrepreneurship scale. Frontiers of entrepreneurship research, 1(1986), 626-639.

Covin, Jeffrey G, \& Slevin, Dennis P. (1989). Strategic management of small firms in hostile and benign environments. Strategic management journal, 10(1),75-87. 
Covin, Jeffrey, G., \& Slevin, Dennis P. (1991). A conceptual model of entrepreneurship as firm behavior. Entrepreneurship theory and practice, 16(1), 7-25.

Covin, Jeffrey G, Green, Kimberly M, \& Slevin, Dennis P. (2006). Strategic process effects on the entrepreneurial orientation-sales growth rate relationship. Entrepreneurship Theory and Practice, 30(1), 57-81.

Dada, Olufunmilola Lola, \& Watson, Anna. (2013). Entrepreneurial orientation and the franchise system: Organisational antecedents and performance outcomes. European Journal of Marketing, 47(5/6), 790-812.

Davis, J. L. (2007). Firm-Level Entrepreneurship and Performance: An Examination and Extension of Relationships and Measurements of the entrepreneurial orientation (EO) Construct. University of Texas at Arlington, Arlington.

Dickson, Peter R, \& Giglierano, Joseph J. (1986). Missing the boat and sinking the boat: a conceptual model of entrepreneurial risk. The Journal of Marketing, 58- 70.

Dimitratos, Pavlos, Lioukas, Spyros, \& Carter, Sara. (2004). The relationship between entrepreneurship and international performance: the importance of domestic environment. International Business Review, 13(1),19-41.

Drucker, P. F. (1985). Innovation and entrepreneurship. Oxford: Butterworth- Heinemann Ltd.

Dwairi, Musa, Bhuian, Shahid N., \& Jurkus, Anthony. (2007). Revisiting the pioneering market orientation model in an emerging economy. European Journal of Marketing, 41(7/8),713-721.

Farrukh, M., Chong, W. Y., Mansori, S., \& Ravan Ramzani, S. (2017). Intrapreneurial behaviour: the role of organizational commitment. World Journal of Entrepreneurship, Management and Sustainable Development, 13(3), 243-256. https://doi.org/10.1108/WJEMSD-03-2017-0016

Farrukh, M., Khan, A. A., Khan, A. A., Shahid Khan, M., Shahid Khan, M., Ravan Ramzani, S., ... Soladoye, B. S. A. (2017). Entrepreneurial intentions: the role of family factors, personality traits and self-efficacy. World Journal of Entrepreneurship, Management and Sustainable Development, 13(4), 303-317.

Farrukh, M., Wei Ying, C., \& Abdallah Ahmed, N. O. (2016). Organizational commitment: Does religiosity matter? Cogent Business \& Management, 3(1), 1-10. https://doi.org/10.1080/23311975.2016.1239300.

Farrukh, M., Ying, C. W., \& Mansori, S. (2017). Organizational commitment: an empirical analysis of personality traits. Journal of Work-Applied Management, 9(1), 18-34.

Farrukh, M., Ying, C., \& Mansori, S. (2016). Intrapreneurial behavior: an empirical investigation of personality traits Research issue. Management \& Marketing. Challenges for 
the

Knowledge

Society,

11(4),

597-609.

https://doi.org/10.1515/mmcks-2016-0018.Introduction.

Finkelstein, S., \& Hambrick, D. C. (1996). Strategic Leadership: Top executives and their effects on organizations. New York: West.

Fornell, C., \& Larcker, D. F. (1981). Evaluating structural equation models with unobservable variables and measurement error. Journal of marketing research, 39-50.

Frank, H., Kessler, A., \& Fink, M. (2010). Entrepreneurial orientation and business performance-a replication study. Schmalenbach Business Review, 62, 175-198.

George, Gerard, Robley Wood Jr, D., \& Khan, R. (2001). Networking strategy of boards: implications for small and medium-sized enterprises. Entrepreneurship \& Regional Development, 13(3), 269-285.

Hitt, Michael A, Hoskisson, Robert E, \& Nixon, Robert D. (1993). A mid-range theory of interfunctional integration, its antecedents and outcomes. Journal of Engineering and Technology Management, 10(1), 161-185.

Hughes, Mathew, \& Morgan, Robert E. (2007). Deconstructing the relationship between entrepreneurial orientation and business performance at the embryonic stage of firm growth. Industrial Marketing Management, 36(5), 651-661.

Hurley, Robert F, Hult, G Tomas M, \& Knight, Gary A. (2005). Innovativeness and capacity to innovate in a complexity of firm-level relationships: A response to Woodside (2004). Industrial Marketing Management, 34(3), 281-283.

Jalali, Seyed Hossein. (2012). Environmental determinants, entrepreneurial orientation and export performance: empirical evidence from Iran. Serbian Journal of Management, 7(2), 245-255.

Jaworski, Bernard, J., \& Kohli, Ajay K. (1993). Market orientation: antecedents and consequences. The Journal of marketing, 53-70.

Jing, Fenwick Feng, \& Avery, Gayle C. (2011). Missing links in understanding the relationship between leadership and organizational performance. International Business \& Economics Research Journal (IBER), 7(5).

Kaplan, R. S. \& Norton, D. P. (2000). The strategy-focused organization. USA: Harvard Business School Press.

Kaplan, R. S., \& Norton, D.P. (1992). The balanced scorecard - measures that drive Performance. Harvard Business Review, January-February, 70-79.

Kaya, Nihat, \& Seyrek, Ibrahim H. (2005). Performance impacts of strategic orientations: Evidence from Turkish manufacturing firms. Journal of American Academy of Business, 6(1), 68-71. 
Keh, Hean Tat, Nguyen, Thi Tuyet Mai, \& Ng, Hwei Ping. (2007). The effects of entrepreneurial orientation and marketing information on the performance of SMEs. Journal of Business Venturing, 22(4), 592-611.

Khandwalla, P. (1977). The design of organization. New York,NY.: Harcourt Brace Jovanovich.

Kimberly, J. R. (Ed.). (1981). Managerial innovation (Vol. 1). New York, NY.: Oxford University Press.

Knight, G.A.(1997). Cross-cultural reliability and validity of a scale to measure firm entrepreneurial orientation (EO). Journal of Business Venturing, 12, 213-225.

Kraus, Sascha, \& Kauranen, Ilkka. (2009). Strategic management and entrepreneurship: friends or foes. International Journal of Business Science and Applied Management, 4(1), 37-50.

Kraus, Sascha, Rigtering, JP Coen, Hughes, Mathew, \& Hosman, Vincent. (2012). Entrepreneurial orientation and the business performance of SMEs: a quantitative study from the Netherlands. Review of Managerial Science, 6(2), 161-182.

Lazer, W., \& Hardin, D. (Eds.). (1994). Entrepreneurship in LCDs: Perspectives and Experience. Wesport, Connecticut: Quorum Books.

Li, Y., Huang, J., \& Tsai, M. (2009). Entrepreneurial orientation (EO) and firm performance: The role of knowledge creation process. Industrial Marketing Management, 38, 440-449.

Li, Yuan, Liu, Yi, \& Liu, Heng. (2011). Co-opetition, distributor's entrepreneurial orientation and manufacturer's knowledge acquisition: Evidence from China. Journal of Operations Management, 29(1), 128-142.

Lumpkin, G Tom, \& Dess, Gregory G. (1996). Clarifying the entrepreneurial orientation construct and linking it to performance. Academy of management Review, 21(1), 135-172.

Lumpkin, George T, \& Dess, Gregory G. (2001). Linking two dimensions of entrepreneurial orientation to firm performance: The moderating role of environment and industry life cycle. Journal of business venturing, 16(5), 429- 451.

Macinati, Manuela S. (2008). The relationship between quality management systems and organizational performance in the Italian National Health Service. Health Policy, 85(2), 228-241.

Mahmood, Rosli, \& Hanafi, Norshafizah. (2013). Entrepreneurial Orientation and Business Performance of Women-Owned Small and Medium Entreprises in Malaysia: Competitive Advantage as a Mediator. International Journal of Business and Social Science, 4(1), 82-90.

Mar Fuentes-Fuentes, M, Albacete-Sáez, Carlos A, \& Lloréns-Montes, F Javier. (2004). The impact of environmental characteristics on TQM principles and organizational performance. 
Omega, 32(6), 425-442.

Miller, Danny, \& Friesen, Peter H. (1978). Archetypes of strategy formulation. Management science, 24(9), 921-933.

Miller, Danny, \& Friesen, Peter H. (1982). Innovation in conservative and entrepreneurial firms: two models of strategic momentum. Strategic management journal, 3(1),1-25.

Miller, Danny. (1983). The correlates of entrepreneurship in three types of firms. Management science, 29(7), 770-791.

Morris, Michael H, \& Sexton, Donald L. (1996). The concept of entrepreneurial intensity: Implications for company performance. Journal of Business Research, 36(1), 5-13.

Osman, Mohd Hassan Mohd, Rashid, Muhammad Amir, Ahmad, Fauziah Sheikh, \& Rajput, Amer. (2011). MARKET ORIENTATION-A MISSING LINK TO SUCCESSFUL WOMEN ENTREPRENEURSHIP IN DEVELOPING

Riaz, Q., Farrukh, M., Rehman, S. U., \& Ishaque, A. (2016). Religion and entrepreneurial intentions: an empirical investigation. International Journal of Advanced and Applied Sciences, 3(9), 31-36.

Saeed, Saadat, Yousafzai, Shumaila Y, \& Engelen, Andreas. (2014). On Cultural and Macroeconomic Contingencies of the Entrepreneurial Orientation-Performance Relationship. Entrepreneurship Theory and Practice, 38(2), 255-290.

Sciascia, Salvatore, D‘Oria, Laura, Bruni, Massimiliano, \& Larrañeta, Bárbara. (2014). Entrepreneurial Orientation in low-and medium-tech industries: The need for Absorptive Capacity to increase performance. European Management Journal.

Shahzad, I. A., Farrukh, M., Kanwal, N., \& Sakib, A. (2018). Decision-making participation eulogizes probability of behavioral output; job satisfaction, and employee performance (evidence from professionals having low and high levels of perceived organizational support). World Journal of Entrepreneurship, Management and Sustainable Development.

Shane, Scott, \& Venkataraman, Sankaran. (2000). The promise of entrepreneurship as a field of research. Academy of management review, 25(1), 217-226.

Sharma, Astha, \& Dave, Sumita. (2011). Entrepreneurial Orientation: Performance Level. SCMS Journal of Indian Management, 8(4).

Simpson, M., Padmore, J., \& Newman, N. (2012). Towards a new model of success and performance in SMEs. International Journal of Entrepreneurial Behavior \& Research, 18(3), 264-285.

Slater, Stanley F, \& Narver, John C. (2000). The positive effect of a market orientation on business profitability: a balanced replication. Journal of business research, 48(1), 69-73.

Smart, Denise T, \& Conant, Jeffrey S. (2011). Entrepreneurial orientation, distinctive 
marketing competencies and organizational performance. Journal of Applied Business Research (JABR), 10(3), 28-38.

Tang, Zhi, \& Tang, Jintong. (2012). Entrepreneurial orientation and SME performance in China's changing environment: The moderating effects of strategies. Asia Pacific Journal of Management, 29(2), 409-431.

Walter, Achim, Auer, Michael, \& Ritter, Thomas. (2006). The impact of network capabilities and entrepreneurial orientation on university spin-off performance. Journal of Business Venturing, 21(4), 541-567.

Wang, Hsing-Kuo, \& Yen, Yu-Fang. (2012). An empirical exploration of corporate entrepreneurial orientation and performance in Taiwanese SMEs: a perspective of multidimensional construct. Total Quality Management \& Business Excellence, 23(9-10),1035-1044.

Wiklund, Johan, \& Shepherd, Dean. (2003). Knowledge-based resources, entrepreneurial orientation, and the performance of small and medium-sized businesses. Strategic management journal, 24(13), 1307-1314.

Wiklund, Johan, \& Shepherd, Dean. (2005). Entrepreneurial orientation and small business performance: a configurational approach. Journal of business venturing, 20(1),71-91.

Wiklund, Johan. (1999). The Sustainability of the TQ; Entrepreneurial Orientation-Performance Relationship.

Zahra, S.A. (1986). A Canonical Analysis of Corporate Entrepreneurship Antecedents and Impact on Performance. Proceedings of the National Academy of Management, 46, 71-5.

Zahra, Shaker A, \& Covin, Jeffrey G. (1995). Contextual influences on the corporate entrepreneurship-performance relationship: A longitudinal analysis. Journal of business venturing, 10(1), 43-58.

Zahra, Shaker A. (1991). Predictors and financial outcomes of corporate entrepreneurship: An exploratory study. Journal of business venturing, 6(4), 259-285.

Zhang, Yanlong, \& Zhang, Xiu'e. (2012). The effect of entrepreneurial orientation on business performance: A role of network capabilities in China. Journal of Chinese Entrepreneurship, 4(2), 132-142.

\section{Copyright}

Copyright for this article is retained by the author(s), with first publication rights granted to the journal.

This is an open-access article distributed under the terms and conditions of the Creative Commons Attribution license (http://creativecommons.org/licenses/by/4.0/). 